\title{
設計用雪荷重評価のための年最大地上積雪深の確率・統計解析 STATISTICAL ANALYSIS OF ANNUAL EXTREME GROUND SNOW DEPTHS FOR STRUCTURAL DESIGN
}

\author{
“桜井修次*, 城 \\ 攻** \\ Shuji SAKURAI and Osamu JOH
}

\begin{abstract}
The purpose of this paper is to discuss the statistical distribution of snow load and the regional property of snow load factor in Load and Resistance Factor Design method according to annual extreme ground snow depths measured at 362 points in Japan. The probability plot correlation coefficient test proposed by Filliben is used for testing five types of probability distribution functions for their goodness of fit to the data samples. The analysis shows that type I and type III distributions are adequate to describe the obserbed annual extreme ground snow depths in Japan. Snow load factors in combination of dead load and snow load are also discussed.
\end{abstract}

Keywords : snow load, probability distribution, mean recurrence interval value, snow load factor 雪荷重, 確率分布形, 再現期待値, 雪荷重係数

\section{1. まえがき}

建築物設計用の雪荷重は，地上積雪荷重およびそれを 屋根雪荷重へ変換するための各種係数とを用いて評価さ れる。地上積雪荷重の確率・統計的性質については，積 雪重量の観測資料がきわめて少ない現状から，全国的に 整備されている積雪深の観測資料を基にして考察される ことが多い。この際に年最大積雪深記録に適合する確率 分布形の選定は，最も重要な事項の一つである。前田刘 は北陸地方の 3 地点について極値 I 型分布, II 型分布お よび対数正規分布を用いて検討した結果，実用的には対 数正規分布が適用できるとしている。和泉ら文21は全国 423 地点の観測記録に対して 5 種の確率分布形（極値 I 型分布，II型分布， III型分布，正規分布および対数正規 分布）の適合度を判定した結果，年最大積雪深の統計的 性質は唯一の分布形では表されないことを指摘し，I型 極值確率紙上で観測值の上位 $1 / 3$ に回帰直線をあてはめ て再胃期待値を推定する方法を提案している。

また, 鋼構造荷重・耐力係数設計法試案 (1986 年) (以 下, LRFD 試案と略す) および鋼構造限界状態設計規 準（案）(1990 年) (以下, 規準案と略す)では, 終局 限界状態においてそれぞれ極值 I 型分布, 対数正規分布 を採用しているが，できるだけ多数の観測地点の記録を 基にした全国的な検討が必要であると思われる。

確率分布形の観測記録への適合度の優劣の尺度として
は規準化誤差文2あるいは二乗推定誤差齐が用いられ， 分布形の相対的な適合度の順位が判定されることが多 い。しかし, 適合度順位 1 位と 2 位以下の誤差値が僅差 であったり，また順位が 2 位以下であっても誤差值が小 さい場合では，2 位以下の分布形を捨ててしまう不都合 を生じる。これに対し，Filliben神 は判定の尺度とし て標本についての順序統計量之確率分布関数の順序統計 量のメディアンとの相関係数 $r$ を用いることを提唱し， かつ正規分布については $r$ 值の検定を行うために必要 な数表を与えている。この検定法が小標本にも有効であ り，非対称分布へも容易に拡張できる利点が強調されて いる。本稿の目的の一つは, Filliben の検定法を極値 I 型分布，II型分布， III型分布まで抁張し，正規分布，対 数正規分布と併せて 5 種の確率分布形の中から全国一律 に用いることのできる分布形の選択を行うことであり， その確率・統計的根拠を明らかにすることである。各地 の確率分布形を単一なものに特定できれば，今日検討さ れている信頼性理論に基づいた設計法の展開を容易にし 得ると言える。二つめは, 適合度の高い分布形と適合度 の低い分布形の違いが, 再現期待偡そのものに与える差 違を考察することである。三つめは，選定された確率分 布形に基づき荷重・耐力係数設計式における雪荷重係数 の各地の値について，その地域分布を明らかにすること である。ただし，荷重係数の算出については，坂本・河
* 北海学園大学工学部建築学科 教授.工修

** 北游道大学工学部建築工学科 助教授. 工博
Prof., Dept. of Architecture, Faculty of Engineering, Univ. of Hokkaigakuen, M. Eng.

Assoc. Prof., Dept. of Architecture, Faculty of Engineering, Univ. of Hokkaido, Dr. Eng. 


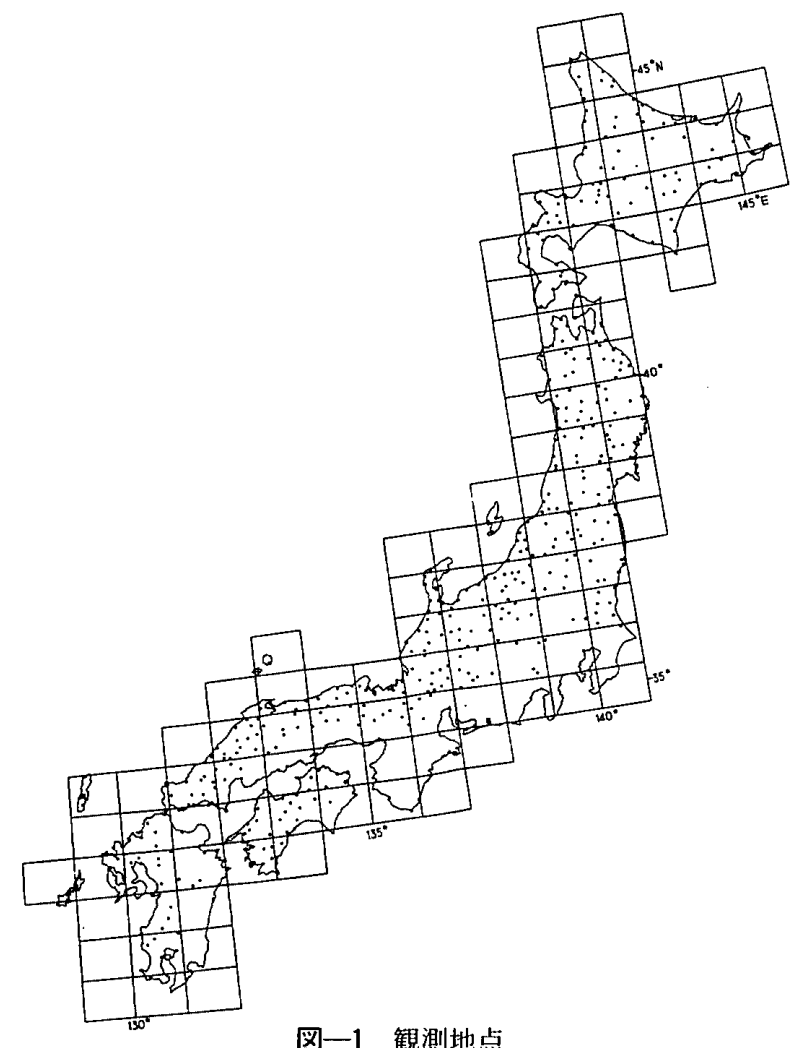

野の研究站にによって多数の荷重の確率過程の組み合わ せを合理的に取り扱う方法が開発され，規準案に反映さ れているが，ここでは確率変数のみで扱うことのできる 雪荷重十固定荷重の場合を対象としている。

\section{2. 解析に用いた資料}

筆者らが参画した建設省総合技術開発プロジェクト 「雪に強い都市づくりに関する総合技術の開発」建築構 造部会（1982～86 年)（以下，総プロと略す）によって, 気象庁の公開資料である全国 423 地点における毎日の地 上積雪深の観測記録（統計期間 1916 1983 年）がとり まとめられた。本稿ではこの観測記録を用いて年最大積 雪深の解析を行う。観測地点の位置を図一1に示す。

\section{3. 確率分布形の適合度検定}

\subsection{Filliben による確率分布形の適合度検定法}

気象統計值に適合性が良いとされている極值 I 型分布 およびII 型分布，また Ellingwood ら文6)研究によって アメリカ合衆国内の積雪量記録についてはI型分布より 適合する地点が多いと報告された対数正規分布，さらに 極值 III型分布と正規分布を加えた計 5 種の確率分布形の 適合性について検定を行い, 併せて確率分布形の違いに よる再現期待値の相違について考察する。これらの確率 分布関数 $F(x)$ は周知のように次式で表される。 極值 I 型分布 $F(x)=\exp \{-\exp [-\alpha(x-u)]\}$

$$
-\infty<x<+\infty
$$

極值 II 型分布 $F(x)=\exp \left[-(v / x)^{k}\right]$

$$
\begin{gathered}
0 \leqq x<+\infty \\
\text { 極值 III 型分布 } F(x)= \\
\left.\exp \mid-[(\varepsilon-x) /(\varepsilon-w)]^{k}\right\} \\
-\infty<x \leqq \varepsilon
\end{gathered}
$$

対数正規分布 $F(x)=\phi[(\ln x-\lambda) / \zeta]$

ここに $\phi:$ 標準正規確㵏分布関数

$k, u, v, w, \alpha, \varepsilon, \zeta, \lambda$ : 確率分布関数のパラメー 夕

なお，前田刘は，最大極値に関する II 型確率分布関数 $F(x)$ として下限值のパラメータを含んだ一般形刘を用 いて検討している。本稿では，日本建築学会の「設計荷 重の考え方」(設計荷重理論小委員会 1989 年 4 月) ある いは国外の II 型分布の扱い（例えば文献 8)，9））におい ては，その下限值をゼロとして扱うことが一般的なので 上式を用いた。

確率分布形の観測記録への適合度を論ずる場合の尺度 として, Fillibenは1975 年に, 標本についての順序統 計量 $X_{i}$ と確率分布関数の順序統計量のメディアン $M_{i}$ との相関係数 $r$ を用いる方法を提唱している。 すなわち

$$
\begin{aligned}
& r=\sum\left(X_{i}-\bar{X}\right)\left(M_{i}-\bar{M}\right) / \sqrt{\sum\left(X_{i}-\bar{X}\right)^{2} \sum\left(M_{i}-\bar{M}\right)^{2}} \\
& \text { ここに } \\
& M_{i}=\Phi^{-1}\left(m_{i}\right) \\
& \Phi: \text { 確率分布関数 } \\
& m_{i} \text { : 一様分布の順序統計量のメディアン } \\
& \begin{array}{ll}
m_{i}=1-m_{n} & i=1 \\
m_{i}=(i-0.3175) /(n+0.365) & i=2,3, \cdots n-1 \\
m_{i}=0.5^{1 / n} & i=n(n: \text { 標本数 })
\end{array}
\end{aligned}
$$

上式において $r$ 值が 1 に近いほど適合性がよい。

Fillibenは，検定に必要な数表として，無限正規分布母 集団からサイズ $n(n=3 \sim 100)$ の標本をそれぞれ $N$ 回（ $n \leqq 10$ においては $N=10^{5}, n>10$ においでは $N=$ $\left.10^{5} / n\right)$ ランダムに抽出して, 各標本数について得られ た $r$ 值の分布の\%点を与えている。 $r$ 值の\%点は, 確率分布関数の適合度検定において有意水準として用い るものであり，本稿ではFilliben にならいレバルと記 す。対数正規分布については変数を正規分布に対数変換 して上記の適合度検定を行うことができる。筆者らは， I 型分布について, 標本サイズ $n=10 \sim 100$ の飾囲で上 述の方法によって $r$ 值の \% 点表（表一1）を作成した。 II 型分布および型分布については，変数を対数変換す る文9 ことによって同表を用いることができる。各分布 形の未知のパラメー夕は, 観測記録を正規確率紙および 極值確率紙上に上記の $m_{i}$ 值に従ってプロットし, 回州 分析によって決定した。なお而型分布の上限值ににつ いては相関係数 $r$ が最も大きくなるように収钽計算に よって求めた。

\section{2 適合度検定}

筆者らは, 総プロの資料のうち北海道, 東北, 北陸地 
表一 $1 \quad r$ 値の検定表

( $n$ :彞本数)

\begin{tabular}{|c|c|c|c|c|c|c|c|c|c|c|c|c|c|}
\hline $\mathbf{n}$ & 0.005 & 0.010 & 0.025 & 0.050 & 0.100 & 0.250 & $\begin{array}{c}\text { レベル } \\
0.500\end{array}$ & 0.750 & 0.900 & 0.950 & 0.975 & 0.990 & 0.995 \\
\hline 10 & 0.841 & 0.862 & 0.888 & 0.908 & 0.927 & 0.951 & 0.969 & 0.980 & 0.988 & 0.990 & 0.992 & 0.994 & 0.995 \\
\hline $\begin{array}{l}11 \\
12\end{array}$ & $\begin{array}{l}848 \\
854\end{array}$ & $\begin{array}{l}0.867 \\
0.872\end{array}$ & $\begin{array}{l}0.892 \\
0.896\end{array}$ & $\begin{array}{l}0.914 \\
0.916\end{array}$ & $\begin{array}{l}0.932 \\
0.935\end{array}$ & & $\begin{array}{l}0.970 \\
0.977\end{array}$ & & & & & & \\
\hline 13 & $\begin{array}{l}0.854 \\
0.860\end{array}$ & 0.878 & $\begin{array}{l}0.890 \\
0.903\end{array}$ & 0.919 & $\begin{array}{l}0.933 \\
0.938\end{array}$ & $\begin{array}{l}0.950 \\
0.958\end{array}$ & 0.973 & 0.983 & $\begin{array}{l}0.988 \\
0.989\end{array}$ & 0.991 & $\begin{array}{l}0.993 \\
0.993\end{array}$ & $\begin{array}{l}0.994 \\
0.994\end{array}$ & 0.995 \\
\hline 14 & 0.861 & 0.882 & 0.905 & 0.922 & 0.940 & 0.960 & 0.974 & 0.983 & & 0.991 & & 0.994 & 0.995 \\
\hline$\frac{15}{16}$ & 0.867 & 0.886 & 0.909 & $\frac{0.926}{0.071}$ & 0.943 & 0.961 & 0.975 & 0.984 & 0.9 & 0.991 & 0.993 & 0.994 & 0.995 \\
\hline $\begin{array}{l}16 \\
17\end{array}$ & $\begin{array}{l}0.872 \\
0.880\end{array}$ & 0.890 & 0.911 & 0.931 & 0.945 & 0.962 & 0.976 & 0.984 & 0.989 & 0.992 & 0.993 & 0.995 & 0.995 \\
\hline $\begin{array}{l}17 \\
18\end{array}$ & $\begin{array}{l}0.880 \\
0.881\end{array}$ & $\begin{array}{l}0.894 \\
0.897\end{array}$ & $\begin{array}{l}0.916 \\
0.918\end{array}$ & $\begin{array}{l}0.933 \\
0.934\end{array}$ & $\begin{array}{l}0.948 \\
0.949\end{array}$ & $\begin{array}{l}0.964 \\
0.965\end{array}$ & $\begin{array}{l}0.977 \\
0.977\end{array}$ & $\begin{array}{l}0.985 \\
0.985\end{array}$ & $\begin{array}{l}0.990 \\
0.990\end{array}$ & $\begin{array}{l}0.992 \\
0.992\end{array}$ & $\begin{array}{l}0.993 \\
0.003\end{array}$ & 0.995 & 0.995 \\
\hline 19 & 0.882 & 0.897 & 0.920 & 0.936 & 0.950 & $\begin{array}{l}0.905 \\
0.966\end{array}$ & 0.978 & $\begin{array}{l}0.985 \\
0.985\end{array}$ & 0.990 & $\begin{array}{l}0.992 \\
0.992\end{array}$ & $\begin{array}{l}0.993 \\
0.994\end{array}$ & $\begin{array}{l}0.993 \\
0.995\end{array}$ & $\begin{array}{l}0.9995 \\
0.995\end{array}$ \\
\hline 20 & 0.883 & 0.902 & 0.922 & 0.938 & 0,951 & 0.967 & 0.979 & 0.986 & 0.990 & 0.992 & 0.994 & 0.995 & 0.995 \\
\hline 21 & 0.887 & 0.904 & 0.923 & 0.939 & 0.953 & 0.968 & 0.980 & 0.986 & 0.991 & 0.993 & 0.994 & 0.995 & 0.996 \\
\hline $\begin{array}{l}22 \\
23\end{array}$ & $\begin{array}{l}0.889 \\
0.892\end{array}$ & $\begin{array}{l}0.905 \\
0.906\end{array}$ & $\begin{array}{l}0.925 \\
0.928\end{array}$ & $\begin{array}{l}0.940 \\
0.943\end{array}$ & $\begin{array}{l}0.954 \\
0.955\end{array}$ & $\begin{array}{l}0.969 \\
0.970\end{array}$ & $\begin{array}{l}0.980 \\
0.981\end{array}$ & $\begin{array}{l}0.987 \\
0.987\end{array}$ & $\begin{array}{l}0.991 \\
0.991\end{array}$ & $\begin{array}{l}0.993 \\
0.993\end{array}$ & $\begin{array}{l}0.994 \\
0.994\end{array}$ & $\begin{array}{l}0.995 \\
0.995\end{array}$ & $\begin{array}{l}0.996 \\
0.996\end{array}$ \\
\hline 24 & 0.895 & 0.907 & 0.930 & 0.944 & 0.957 & 0.971 & 0.981 & 0.987 & 0.991 & 0.993 & 0.994 & 0.995 & 0.996 \\
\hline$\frac{25}{26}$ & & 0.906 & 0.929 & 0.946 & 0.958 & 0.972 & 0.982 & 0.988 & 0.992 & 0.993 & 0.994 & 0.995 & 0.996 \\
\hline 26 & 0.897 & 0.910 & 0.929 & 0.948 & 0.959 & 0.973 & 0.982 & 0.988 & 0.992 & 0.993 & 0.994 & 0.995 & 0.996 \\
\hline 27 & 0.899 & 0.913 & 0.932 & 0.950 & 0.960 & 0.973 & 0.982 & 0.989 & 0.992 & 0.993 & 0.995 & 0.996 & 0.996 \\
\hline 28 & 0.901 & 0.914 & 0.933 & $\begin{array}{l}0.950 \\
0.951\end{array}$ & 0.961 & 0.974 & 0.983 & 0.989 & 0.992 & 0.994 & 0.995 & 0.996 & 0.996 \\
\hline $\begin{array}{l}29 \\
30 \\
\end{array}$ & $\begin{array}{l}0.903 \\
0.909 \\
\end{array}$ & $\begin{array}{l}0.914 \\
0.916 \\
\end{array}$ & $\begin{array}{l}0.935 \\
0.936 \\
\end{array}$ & $\begin{array}{l}0.951 \\
0.952 \\
\end{array}$ & $\begin{array}{l}0.962 \\
0.963 \\
\end{array}$ & $\begin{array}{l}0.975 \\
0.975 \\
\end{array}$ & $\begin{array}{r}0.984 \\
0.984 \\
\end{array}$ & $\begin{array}{l}0.989 \\
0.989 \\
\end{array}$ & $\begin{array}{l}0.992 \\
0.992 \\
\end{array}$ & $\begin{array}{l}0.994 \\
0.994\end{array}$ & $\begin{array}{l}0.995 \\
0.995\end{array}$ & $\begin{array}{l}0.996 \\
0.996\end{array}$ & $\begin{array}{l}0.996 \\
0.996\end{array}$ \\
\hline 31 & 0.908 & 0.918 & 0.937 & 0.953 & 0.964 & 0.975 & 0.984 & 0.989 & 0.992 & 0.994 & 0.995 & 0.996 & 0.997 \\
\hline $\begin{array}{l}32 \\
33\end{array}$ & $\begin{array}{l}0.908 \\
0.913\end{array}$ & $\begin{array}{l}0.920 \\
0.922\end{array}$ & 0.941 & $\begin{array}{l}0.953 \\
0.955\end{array}$ & 0.964 & 0.976 & $\begin{array}{l}0.984 \\
0.985\end{array}$ & 0.990 & $\begin{array}{l}0.993 \\
0.993\end{array}$ & $\begin{array}{l}0.994 \\
0.994\end{array}$ & $\begin{array}{l}0.995 \\
0.995\end{array}$ & $\begin{array}{l}0.996 \\
0.996\end{array}$ & 0.996 \\
\hline 34 & 0.919 & $\begin{array}{l}0.922 \\
0.926\end{array}$ & $\begin{array}{l}0.941 \\
0.944\end{array}$ & 0.956 & $\begin{array}{l}0.965 \\
0.966\end{array}$ & $\begin{array}{l}0.977 \\
0.977\end{array}$ & 0.985 & $\begin{array}{l}0.990 \\
0.990\end{array}$ & 0.993 & $\begin{array}{l}0.994 \\
0.994\end{array}$ & 0.995 & 0.996 & $\begin{array}{l}0.996 \\
0.996\end{array}$ \\
\hline$\frac{35}{36}$ & 0.920 & 0.928 & 0.944 & $\frac{0.957}{0.950}$ & 0.967 & 0.978 & 0.985 & 0.990 & 0.993 & 0.994 & 0.995 & 0.996 & 0.996 \\
\hline $\begin{array}{l}36 \\
37\end{array}$ & $\begin{array}{l}0.918 \\
0.921\end{array}$ & $\begin{array}{l}0.927 \\
0.930\end{array}$ & $\begin{array}{l}0.945 \\
0.946\end{array}$ & $\begin{array}{l}0.959 \\
0.959\end{array}$ & $\begin{array}{l}0.967 \\
0.968\end{array}$ & $\begin{array}{l}0.978 \\
0.979\end{array}$ & $\begin{array}{l}0.986 \\
0.986\end{array}$ & $\begin{array}{l}0.990 \\
0.991\end{array}$ & $\begin{array}{l}0.993 \\
0.993\end{array}$ & $\begin{array}{l}0.995 \\
0.995\end{array}$ & $\begin{array}{l}0.995 \\
0.995\end{array}$ & $\begin{array}{l}0.996 \\
0.996\end{array}$ & $\begin{array}{l}0.997 \\
0.997\end{array}$ \\
\hline 38 & 0.920 & 0.930 & 0.946 & 0.959 & 0.969 & 0.979 & 0.986 & 0.991 & 0.993 & 0.995 & 0.995 & 0.996 & 0.997 \\
\hline $\begin{array}{l}39 \\
40\end{array}$ & $\begin{array}{l}0.928 \\
0.923\end{array}$ & $\begin{array}{l}0.932 \\
0.934\end{array}$ & $\begin{array}{l}0.949 \\
0.951\end{array}$ & $\begin{array}{l}0.960 \\
0.960\end{array}$ & $\begin{array}{l}0.970 \\
0.970\end{array}$ & $\begin{array}{l}0.979 \\
0.980\end{array}$ & $\begin{array}{l}0.986 \\
0.986\end{array}$ & $\begin{array}{l}0.991 \\
0.991\end{array}$ & $\begin{array}{l}0.994 \\
0.994\end{array}$ & $\begin{array}{l}0.995 \\
0.995\end{array}$ & $\begin{array}{l}0.996 \\
0.996\end{array}$ & $\begin{array}{l}0.996 \\
0.996\end{array}$ & $\begin{array}{l}0.997 \\
0.997\end{array}$ \\
\hline 41 & 0.931 & 0.935 & 0.951 & 0.961 & 0.971 & 0.980 & 0.987 & 0.991 & 0.994 & 0.995 & 0.996 & 0.997 & 0.997 \\
\hline 42 & 0.932 & 0.936 & 0.953 & 0.962 & 0.970 & 0.980 & 0.987 & 0.991 & 0.994 & 0.995 & & 0.996 & 0.997 \\
\hline 43 & 0.931 & 0.938 & 0.952 & 0.962 & 0.971 & 0.981 & 0.987 & 0.991 & 0.994 & 0.995 & 0.996 & 0.997 & 0.997 \\
\hline & $\begin{array}{l}0.929 \\
0.927\end{array}$ & 0.939 & 0.953 & 0.963 & 0.971 & 0.981 & 0.987 & 0.992 & 0.994 & 0.995 & 0.996 & 0.997 & 0.997 \\
\hline 6 & $\frac{0.927}{0.928}$ & 0.938 & & & .972 & 0.9 & & & 0.994 & 0.995 & 0.9 & & 0.297 \\
\hline $\begin{array}{l}46 \\
47\end{array}$ & $\begin{array}{l}0.928 \\
0.932\end{array}$ & 0.940 & 0.953 & 0.962 & 0.972 & 0.981 & 0.988 & 0.992 & 0.994 & 0.995 & 0.996 & 0.997 & 0.997 \\
\hline $\begin{array}{l}47 \\
48\end{array}$ & $\begin{array}{l}0.932 \\
0.933\end{array}$ & $\begin{array}{l}0.942 \\
0.942\end{array}$ & 0.954 & $\begin{array}{l}0.963 \\
0.963\end{array}$ & $\begin{array}{l}0.972 \\
0.972\end{array}$ & $\begin{array}{l}0.982 \\
0.982\end{array}$ & 0.988 & $\begin{array}{l}0.992 \\
0.992\end{array}$ & 0.994 & $\begin{array}{l}0.995 \\
0.995\end{array}$ & 0.996 & 0.997 & 0.997 \\
\hline $\begin{array}{l}40 \\
49\end{array}$ & 0.933 & & $\begin{array}{l}0.955 \\
0.956\end{array}$ & $\begin{array}{l}0.963 \\
0.964\end{array}$ & $\begin{array}{l}0.912 \\
0.972\end{array}$ & $\begin{array}{l}0.982 \\
0.982\end{array}$ & $\begin{array}{l}0.988 \\
0.988\end{array}$ & $\begin{array}{l}0.992 \\
0.992\end{array}$ & $\begin{array}{l}0.994 \\
0.994\end{array}$ & $\begin{array}{l}0.995 \\
0.995\end{array}$ & $\begin{array}{l}0.996 \\
0.996\end{array}$ & $\begin{array}{l}0.997 \\
0.997\end{array}$ & $\begin{array}{l}0.997 \\
0.997\end{array}$ \\
\hline 50 & 0.933 & 0.946 & 0.955 & 34 & 0.972 & 0.982 & 0.988 & 0,992 & 0.994 & 0.995 & $\begin{array}{r}0.996 \\
\end{array}$ & 0.997 & 0.997 \\
\hline 51 & 0.932 & 0.946 & 0.954 & 0.964 & 0.973 & 0.982 & 0.989 & 0.992 & 0.994 & $0: 995$ & 0.996 & 0.997 & 0.997 \\
\hline 52 & $\begin{array}{l}0.936 \\
0.937\end{array}$ & 0.944 & $\begin{array}{l}0.956 \\
0.957\end{array}$ & 0.964 & $\begin{array}{l}0.973 \\
0.974\end{array}$ & $\begin{array}{l}0.983 \\
0.983\end{array}$ & $\begin{array}{l}0.989 \\
0.989\end{array}$ & $\begin{array}{l}0.992 \\
0.093\end{array}$ & $\begin{array}{l}0.995 \\
0.995\end{array}$ & $\begin{array}{l}0.996 \\
0.996\end{array}$ & $\begin{array}{l}0.996 \\
0.996\end{array}$ & $\begin{array}{l}0.997 \\
0.907\end{array}$ & $\begin{array}{l}0.997 \\
0.997\end{array}$ \\
\hline $\begin{array}{l}53 \\
54\end{array}$ & $\begin{array}{l}0.937 \\
0.939\end{array}$ & $\begin{array}{l}0.947 \\
0.948\end{array}$ & $\begin{array}{l}0.957 \\
0.958\end{array}$ & $\begin{array}{l}0.9666 \\
0.966\end{array}$ & $\begin{array}{l}0.974 \\
0.974\end{array}$ & $\begin{array}{l}0.983 \\
0.983\end{array}$ & $\begin{array}{l}0.989 \\
0.989\end{array}$ & $\begin{array}{l}0.993 \\
0.993\end{array}$ & $\begin{array}{l}0.995 \\
0.995\end{array}$ & $\begin{array}{l}0.996 \\
0.996\end{array}$ & 0.996 & $\begin{array}{l}0.997 \\
0.997\end{array}$ & $\begin{array}{l}0.997 \\
0.997\end{array}$ \\
\hline $\begin{array}{l}34 \\
55 \\
\end{array}$ & $\begin{array}{l}0.945 \\
\end{array}$ & $\begin{array}{r}0.948 \\
0.948 \\
\end{array}$ & $\begin{array}{l}0.938 \\
0.960 \\
\end{array}$ & $\begin{array}{l}0.960 \\
\end{array}$ & $\begin{array}{l}0.914 \\
0.975\end{array}$ & 0.983 & $\begin{array}{l}0.989 \\
0.989 \\
\end{array}$ & $\begin{array}{l}0.993 \\
\end{array}$ & 0.995 & 0.996 & 0.996 & 0.997 & $\begin{array}{l}0.997 \\
\end{array}$ \\
\hline 56 & 0.940 & 0.949 & 0.960 & 0.967 & 0.975 & 0.984 & 0.989 & 0.993 & 0.995 & 0.996 & & 0.997 & 0.997 \\
\hline 57 & 0.940 & 0.950 & 0.960 & 0.967 & 0.975 & 0.984 & 0.990 & 0.993 & & & & & \\
\hline 58 & 0.943 & 0.952 & 0.961 & 0.967 & 0.976 & 0.984 & 0.990 & 0.993 & 0.995 & 0.996 & 0.9 & 0. & 97 \\
\hline 59 & 0.940 & 0.951 & 0.960 & 0.968 & 0.975 & 0.984 & 0.990 & 0.993 & 0.995 & 0.996 & & 0.997 & 0.997 \\
\hline$\frac{60}{61}$ & $\frac{0.941}{0.940}$ & $\frac{0.951}{0.950}$ & $\frac{0.961}{0.961}$ & $\frac{0.969}{0.969}$ & $\frac{0.975}{0.976}$ & $\frac{0.984}{0.985}$ & $\frac{0.990}{0.990}$ & $\frac{0.993}{0.993}$ & $\frac{0.995}{0.995}$ & $\frac{0.996}{0.996}$ & 0.997 & $\frac{0.997}{0.997}$ & $\frac{0.997}{0.997}$ \\
\hline 62 & 0.940 & 0.949 & 0.961 & 0.969 & 0.976 & 0.985 & 0.990 & 0.993 & 0.995 & 0.996 & 0.997 & 0.997 & 0.997 \\
\hline 63 & 0.937 & 0.948 & 0.961 & 0.969 & 0.977 & 0.985 & 0.990 & 0.993 & 0.995 & 0.996 & 0.997 & 0.997 & 0.998 \\
\hline 64 & $\begin{array}{l}0.938 \\
0.938\end{array}$ & $\begin{array}{l}0.951 \\
0.952\end{array}$ & 0.962 & $\begin{array}{l}0.969 \\
0.969\end{array}$ & 0.977 & $\begin{array}{l}0.985 \\
0.986\end{array}$ & $\begin{array}{l}0.990 \\
0.991\end{array}$ & $\begin{array}{l}0.993 \\
0.994\end{array}$ & $\begin{array}{l}0.995 \\
0.995\end{array}$ & $\begin{array}{l}0.996 \\
0.996\end{array}$ & $\begin{array}{l}0.997 \\
0.007\end{array}$ & $\begin{array}{l}0.997 \\
0.097\end{array}$ & 0.997 \\
\hline 66 & 0.939 & 0.952 & 0.962 & 0.970 & 0.978 & 0.986 & $\frac{0.791}{0.991}$ & $\frac{0.284}{0.994}$ & $\frac{0.282}{0.995}$ & $\frac{0.298}{0.996}$ & $\frac{0.991}{0.997}$ & $\frac{0.991}{0.997}$ & $\frac{91}{298}$ \\
\hline 67 & 38 & 0.951 & 0.963 & 0.970 & 0.978 & 0.986 & 0.991 & 0.994 & & & & & \\
\hline 68 & 0. & 0.952 & 0.963 & 0.971 & 0.978 & 0.986 & 0.991 & 0.994 & & & & & \\
\hline 69 & 0.941 & 0.952 & 0.964 & 0.971 & 0.978 & 0.986 & & & & & & & \\
\hline 70 & 0.942 & 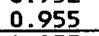 & 0.965 & 0. & 78 & 0.986 & 0.991 & & 0. & 86 & & 0. & 98 \\
\hline 71 & 0.941 & & 0.965 & 0.972 & 0.979 & 0.986 & 0.991 & 0.994 & 0.995 & 0.996 & & 0. & \\
\hline $\begin{array}{l}72 \\
73\end{array}$ & $\begin{array}{l}0.943 \\
0.943\end{array}$ & $\begin{array}{l}0.955 \\
0.954\end{array}$ & $\begin{array}{l}0.965 \\
0.965\end{array}$ & 0.972 & $\begin{array}{l}0.979 \\
0.979\end{array}$ & $\begin{array}{l}0.986 \\
0.986\end{array}$ & $\begin{array}{l}0.991 \\
0.991\end{array}$ & $\begin{array}{l}0.994 \\
0.994\end{array}$ & $\begin{array}{l}0.995 \\
0.996\end{array}$ & $\begin{array}{l}0.996 \\
0.996\end{array}$ & & D. & \\
\hline 74 & 0.943 & $\begin{array}{l}0.954 \\
0.954\end{array}$ & $\begin{array}{l}0.905 \\
0.966\end{array}$ & 0.973 & 0.979 & 0.987 & 0.991 & $\begin{array}{l}0.994 \\
0.994\end{array}$ & $\begin{array}{l}0.996 \\
0.996\end{array}$ & 0.996 & $\begin{array}{l}0.997 \\
0.997\end{array}$ & $\begin{array}{l}0.997 \\
0.997\end{array}$ & $\begin{array}{l}0.997 \\
0.998\end{array}$ \\
\hline 75 & 0.943 & 0.957 & 0.965 & 0.974 & 0.980 & 0.987 & 0.991 & 0.994 & 0.996 & 0.996 & 0.997 & 0.997 & \\
\hline 76 & & & 0.966 & & & & & & & & & & \\
\hline 77 & 0.942 & 0.956 & 0.965 & 0.974 & 0 . & 0.987 & & 0.9 & 0. & & & 0 & 0 \\
\hline 78 & 0.942 & 0.9 & 0.966 & 0.5 & & 37 & & 0. & & & & 0 & \\
\hline 79 & & & 0.967 & 0.974 & & 0.987 & & & & & & & \\
\hline 80 & & & 0.966 & 0.975 & & 0.987 & 0. & ㅇ. & 0 & & & 0 & \\
\hline 81 & 0.947 & 0.955 & 0.966 & 0.974 & 0.981 & 0.988 & 0.9 & 0. & & 0. & & & \\
\hline & & & & & & & & & & & & & \\
\hline & & 0.958 & 0.966 & 0.974 & & 0.988 & 0.992 & 0.994 & & & 0.997 & 0 . & \\
\hline 84 & 0.947 & 0.959 & 0.966 & 0.975 & 0.982 & 0.988 & 0.992 & & 0.996 & & 0.997 & 0.998 & 8 \\
\hline & $\frac{0.950}{0.950}$ & $\begin{array}{l}0.959 \\
0.959\end{array}$ & $\frac{0.966}{0.968}$ & $\frac{0.974}{0.974}$ & $\frac{0.982}{0.981}$ & $\frac{0.988}{0.988}$ & $\frac{0.992}{0.902}$ & $\frac{0.995}{0.95}$ & $\frac{0.996}{0.966}$ & $\frac{0.997}{0.997}$ & 0.997 & $\begin{array}{l}0.998 \\
0.098\end{array}$ & \\
\hline $\begin{array}{l}86 \\
87\end{array}$ & $\begin{array}{l}0.950 \\
0.953 .\end{array}$ & $\begin{array}{l}0.959 \\
0.959\end{array}$ & $\begin{array}{l}0.968 \\
0.968\end{array}$ & $\begin{array}{l}0.974 \\
0.974\end{array}$ & $\begin{array}{l}0.981 \\
0.981\end{array}$ & 0.988 & 0.992 & 0.995 & & 0.997 & & & \\
\hline 88 & 0.953 & 0.959 & 0.968 & 0.975 & 0.982 & 0.988 & 0.992 & 0.995 & & 0.997 & 0.997 & 8 & \\
\hline 89 & & & & & & & & & & & & & \\
\hline & & & & & & & & & & & & & \\
\hline 91 & & 0.959 & $\begin{array}{l}0.968 \\
0.968\end{array}$ & & & 0.989 & 0.993 & 0.965 & & & & & \\
\hline 93 & $\begin{array}{l}0.951 \\
0.952\end{array}$ & $\begin{array}{l}0.959 \\
0.959\end{array}$ & $\begin{array}{l}0.908 \\
0.969\end{array}$ & $\begin{array}{l}0.975 \\
0.976\end{array}$ & $\begin{array}{l}0.982 \\
0.982\end{array}$ & 0.989 & 0.993 & 0.995 & $\begin{array}{l}0.996 \\
0.996\end{array}$ & $\begin{array}{l}0.9977 \\
0.997\end{array}$ & $\begin{array}{l}0.997 \\
0.997\end{array}$ & 8 & \\
\hline 94 & 0.950 & 0.958 & 0.969 & 0.975 & 0.982 & 0.989 & 0.993 & & & 0.997 & 0 & 98 & \\
\hline 25 & 0.950 & 0.958 & 0.967 & 0.976 & 0.982 & 0.989 & 0.993 & 0.995 & 0.996 & 0.997 & 0.997 & 0.998 & 0.298 \\
\hline 96 & 0.950 & 0.959 & 0.967 & 0.976 & 0.982 & 0.989 & 0.993 & 0.995 & 0.996 & 0.997 & 0.997 & 0.998 & 0. \\
\hline 97 & 0.950 & 0.958 & 0.968 & 0.976 & 0.982 & 0.989 & 0.993 & 0.995 & 0.996 & 0.997 & 0.997 & 0.998 & 0.998 \\
\hline 98 & 0.951 & 0.957 & 0.969 & 0.976 & 0.982 & 0.989 & 0.993 & 0.995 & 0.996 & 0.997 & 0.997 & 0.998 & 0.998 \\
\hline $\begin{array}{r}99 \\
100\end{array}$ & $\begin{array}{l}0.953 \\
0.952\end{array}$ & $\begin{array}{l}0.959 \\
0.959\end{array}$ & $\begin{array}{l}0.969 \\
0.968\end{array}$ & $\begin{array}{l}0.976 \\
0.976\end{array}$ & $\begin{array}{l}0.982 \\
0.982\end{array}$ & $\begin{array}{l}0.989 \\
0.989\end{array}$ & $\begin{array}{l}0.993 \\
0.993\end{array}$ & $\begin{array}{l}0.995 \\
0.995\end{array}$ & $\begin{array}{l}0.996 \\
0.996\end{array}$ & $\begin{array}{l}0.997 \\
0.997\end{array}$ & $\begin{array}{l}0.997 \\
0.997\end{array}$ & $\begin{array}{l}0.998 \\
0.998\end{array}$ & $\begin{array}{l}0.998 \\
0.998\end{array}$ \\
\hline
\end{tabular}


表一2 分布形の適合順位と検定レベルに該当する地点数

2-（a）極値 I 型分布

\begin{tabular}{|c|c|c|c|c|}
\hline $\begin{array}{c}\text { 分布形 } \\
\begin{array}{c}\text { 適合 } \\
\text { 顓位 }\end{array}\end{array}$ & $\begin{array}{c}\text { ○ } \\
50 \sim\end{array}$ & $\begin{array}{c}\bigcirc \\
5 \sim 50\end{array}$ & $\begin{array}{c}\Delta \\
1 \sim 5\end{array}$ & $\begin{array}{c}\times \\
\sim 1\end{array}$ \\
\hline 1 & 57 & 41 & 4 & 1 \\
\hline 2 & 64 & 55 & 2 & 0 \\
\hline 3 & 14 & 59 & 18 & 10 \\
\hline 4 & 1 & 25 & 9 & 2 \\
\hline 5 & 0 & 0 & 0 & 0 \\
\hline $\begin{array}{c}\text { 合計 } \\
(\%)\end{array}$ & $\begin{array}{c}136 \\
(38 \%)\end{array}$ & $\begin{array}{c}180 \\
(50 \%)\end{array}$ & $\begin{array}{c}33 \\
(9 \%)\end{array}$ & $\begin{array}{c}13 \\
(3 \%)\end{array}$ \\
\hline
\end{tabular}

2-(d) 正規分布

\begin{tabular}{|c|c|c|c|c|}
\hline \multirow{2}{*}{$\begin{array}{c}\text { 分布形 } \\
\text { 適合 }\end{array}$} & \multicolumn{4}{|c|}{ 検定レベル } \\
\cline { 2 - 5 } & $\begin{array}{c}\bigcirc \\
50 \sim\end{array}$ & $\begin{array}{c}\bigcirc \\
5 \sim 50\end{array}$ & $\begin{array}{c}\triangle \\
1 \sim 5\end{array}$ & $\begin{array}{c}\times \\
\sim 1\end{array}$ \\
\hline 1 & 23 & 11 & 0 & 0 \\
\hline 2 & 27 & 30 & 3 & 0 \\
\hline 3 & 6 & 50 & 11 & 11 \\
\hline 4 & 2 & 47 & 21 & 20 \\
\hline 5 & 0 & 10 & 18 & 72 \\
\hline $\begin{array}{c}\text { 合計 } \\
(\%)\end{array}$ & $\begin{array}{c}58 \\
(16 \%)\end{array}$ & $\begin{array}{c}148 \\
(41 \%)\end{array}$ & $\begin{array}{c}53 \\
(15 \%)\end{array}$ & $\begin{array}{c}103 \\
(28 \%)\end{array}$ \\
\hline
\end{tabular}

方について，Filliben 法によって観測地点ごとに $5 つ の$ 確率分布形それぞれの $r$ 值を求め, その大小を比較し て分布形の適合度判定を行ったが，いずれの分布形も適 合度順位 1 位の地点数が全地点の大半を占めるには至ら なかった文10)。まえがきで述べたように，観测記録の各 確率分布形に対する適合度を検定し分布形の良否を考察 する場合，判定の尺度となる值の大小を比較するだけで は不十分である。このことからレベルが $50 \%$ を超える 場合○印, 5 - 50\%の場合○印, $1 \sim 5 \%$ の場合 $\Delta$ 印, 1 $\%$ 以下の場合 $\times$ 印をつけ検定の目安とした。レベルの 区切りの設定值は確定したものではないが, 少なくとも 数字が高いことが適合度が良いことを表している。本稿 では，統計期間中積雪のない年が多く統計処理のしにく い四国と九州を除いた地域 362 地点の観測記録につい て，上記 5 つの分布形によるあてはめを行う。これらの 地点の統計期間は 1916〜1983 年の範囲にあり，統計年 数は15〜68 年であるが, 多くは1983 年までの 20〜40 冬期である。

表一2(a)〜 (e) に上記の各検定レベルに該当する観測 地点数を示す。また，同表には $r$ 值の大小によって定 まる $5 つ の$ 分布形の中での適合度順位別の地点数も示さ れている。図一2には各レベルに該当する地点数の 362 地点に対する割合を分布形ごとに示すが，レベルが $1 \%$ を超える地点数が最も多いのは而型分布の 353 個（全地 2-(c) 極値四型分布

\begin{tabular}{|c|c|c|c|c|}
\hline \multirow{2}{*}{$\begin{array}{c}\text { 分布形 } \\
\text { 喚合 }\end{array}$} & \multicolumn{4}{|c|}{ 㛟定レベル } \\
\cline { 2 - 5 } & $\begin{array}{c}\bigcirc \\
50 \sim\end{array}$ & $\begin{array}{c}O \\
5 \sim 50\end{array}$ & $\begin{array}{c}\triangle \\
1 \sim 5\end{array}$ & $\begin{array}{c}\times \\
\sim 1\end{array}$ \\
\hline 1 & 155 & 48 & 2 & 0 \\
\hline 2 & 40 & 45 & 3 & 1 \\
\hline 3 & 8 & 29 & 3 & 0 \\
\hline 4 & 0 & 10 & 10 & 8 \\
\hline 5 & 0 & 0 & 0 & 0 \\
\hline $\begin{array}{c}\text { 合計 } \\
(\%)\end{array}$ & $\begin{array}{c}203 \\
(56 \%)\end{array}$ & $\begin{array}{c}132 \\
(37 \%)\end{array}$ & $\begin{array}{c}18 \\
(5 \%)\end{array}$ & $\begin{array}{c}9 \\
(2 \%)\end{array}$ \\
\hline
\end{tabular}

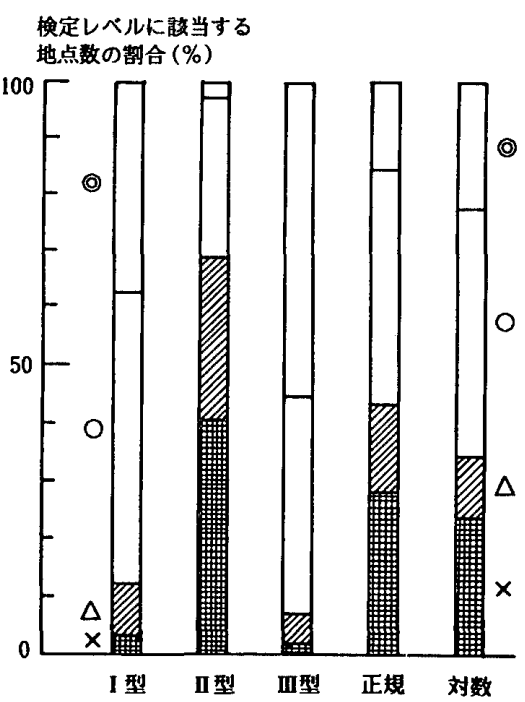

図一2 検定レベルに該当する地点数の割合

点数の $98 \%$ ）であり，次いでI 型分布の 349 俔（同 96 $\%$ ，対数正規分布の 279 個（同 $77 \%$ ), 正規分布の 259 個（同 $72 \%$ )，II 型分布の 216 個（同 $60 \%$ ）の順 となる。また，レベルが $5 \%$ を超える地点数は， III型 分布が 335 個（全地点数の $93 \%$ ），I型分布か 316 個 (同 $88 \%$ ), 対数正規分布 241 個（同 $66 \%$ ), 正規分布 206 個（同 $57 \%$ )，II 型分布 116 個（同 $32 \%$ ）である。 したがって，これらの結果は型分布および I 型分布の 適合度が高いことを表している。これに対し，レベルに よる検定ではなく $r$ 値の大小によって順位づけを行う と, 適合度順位 1 位となる地点数は林型分布が 205 個(全 地点の $57 \%$ ，，I型分布 103 個（同 $28 \%$ ）, 対数正規分 布 100 個（同 $28 \%$ ), 正規分布 34 個（同 $9 \%$ ), II 型分 布では 19 個（同 $5 \%$ ）となり，いずれの分布形も適合 性が低いという結果になる。しかし，順位が 2 位以下で あっても $5 \%$ 検定に合格する地点数は, 表一2 註ら分か るように亚型分布が 132 個（全地点の $36 \%$ ），I型分布 218 個（同 $60 \%$ ，，対数正規分布 144 個（同 $40 \%$ ), 正 規分布 172 個（同 $48 \%$ )，II型分布では 97 個（同 $27 \%$ ) となり各分布形とも相当数の地点を含んでいる。I 型分 


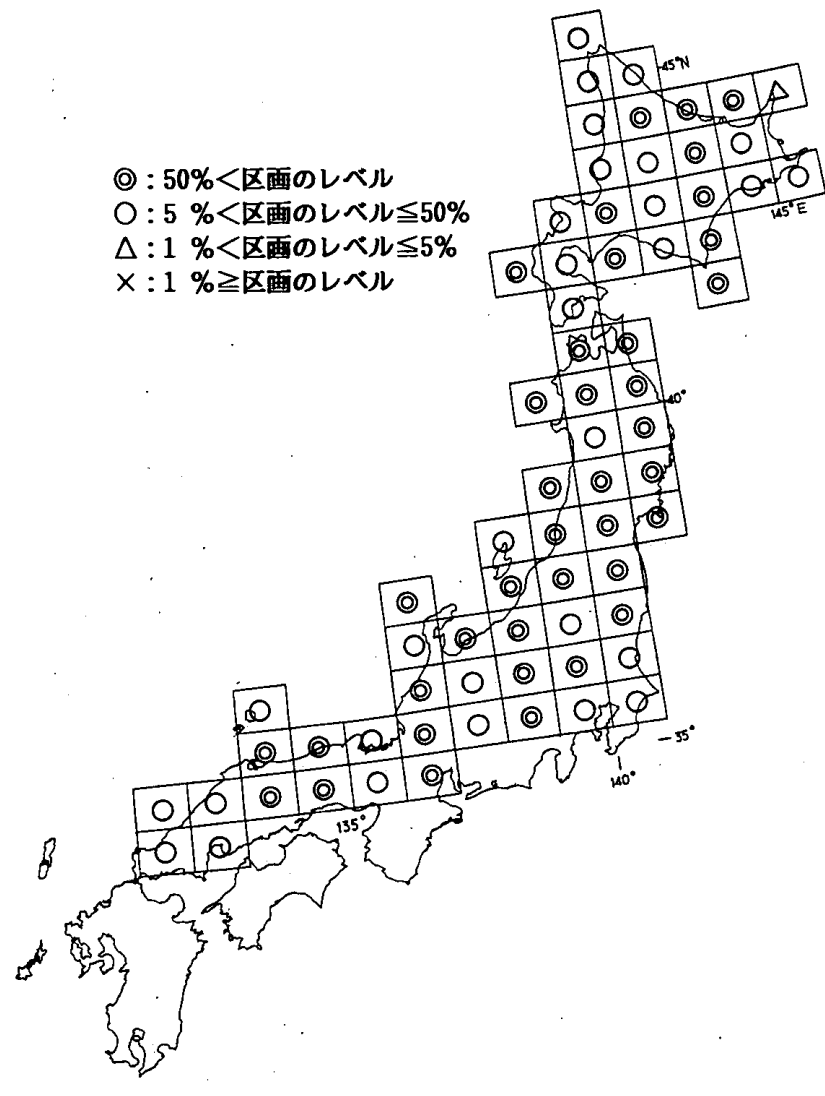

図一3・区画ごとの判定結果（極值 III型分布）

布は対数正規分布より 74 地点多く，このことは I 型分 布が対数正規分布に比べより汎用的に用いることができ る分布形であることを示し，適合度判定としては $r$ 值 による順位づけよりレベルによる検定法がすぐれている ことを示唆している。

雪荷重を確率論的に論じる場合地域ごとの適合度につ いても明らかにする必要がある。本稿では，建設省国土 地理院の国土数值情報による第 1 次地域区画（経度差 1 度, 緯度差 40 分, 日本の中央付近では縦横とも辺長約 $80 \mathrm{~km}$ ) を基準区画として，各区画ごとの適合レベルに ついて考察する。このとき区画内に位置する各観測地点 のレベルのうち, 適合度の高いほうから数えてその半数 を超えるレベルをその区画の.レベルとする。ただし，レ ベルの異なる地点が同数の場合, 2 つのレベルが1ラン ク離れているときは中間のレベルを，連続しているとき は低い方のレベルを用いる。図一1に示したように，区 画内の地点数は 1 14 個の範囲でばらつきがあり，必ず しも十分な地点数を有している区画ばかりではないが, この方法は，適合レベルの地域分布を概観するうえでは 有効であると思われる。5つの分布形のうちレベル検定 による上位の 3 分布すなわち四型分布，I型分布および 対数正規分布についての検討結果を図一 $3,4,5$ に示す。 四型分布之I 型分布は図一 3,4 に示すように全国的にほ ぼ○あるいは○印で表されており，全国一律に用いるこ とのできる分布形であることが分かる。対数正規分布は

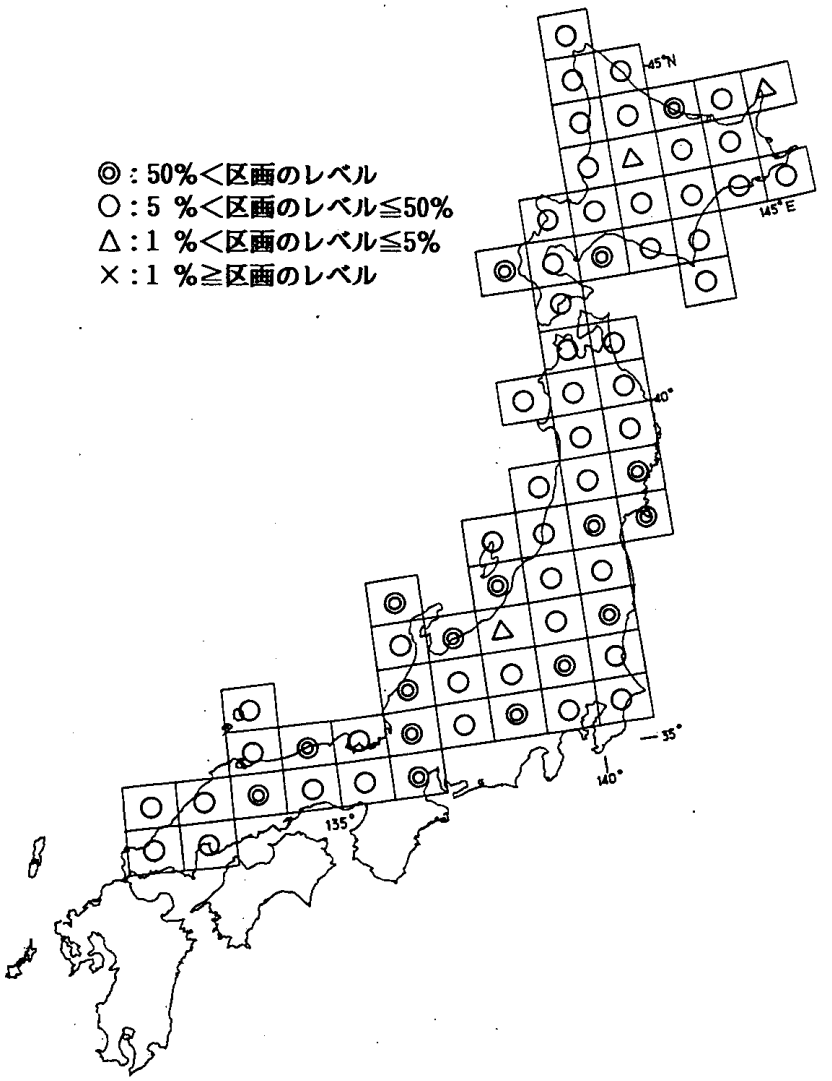

图一4 区画ごとの判定結果（極値Ｉ型分布）

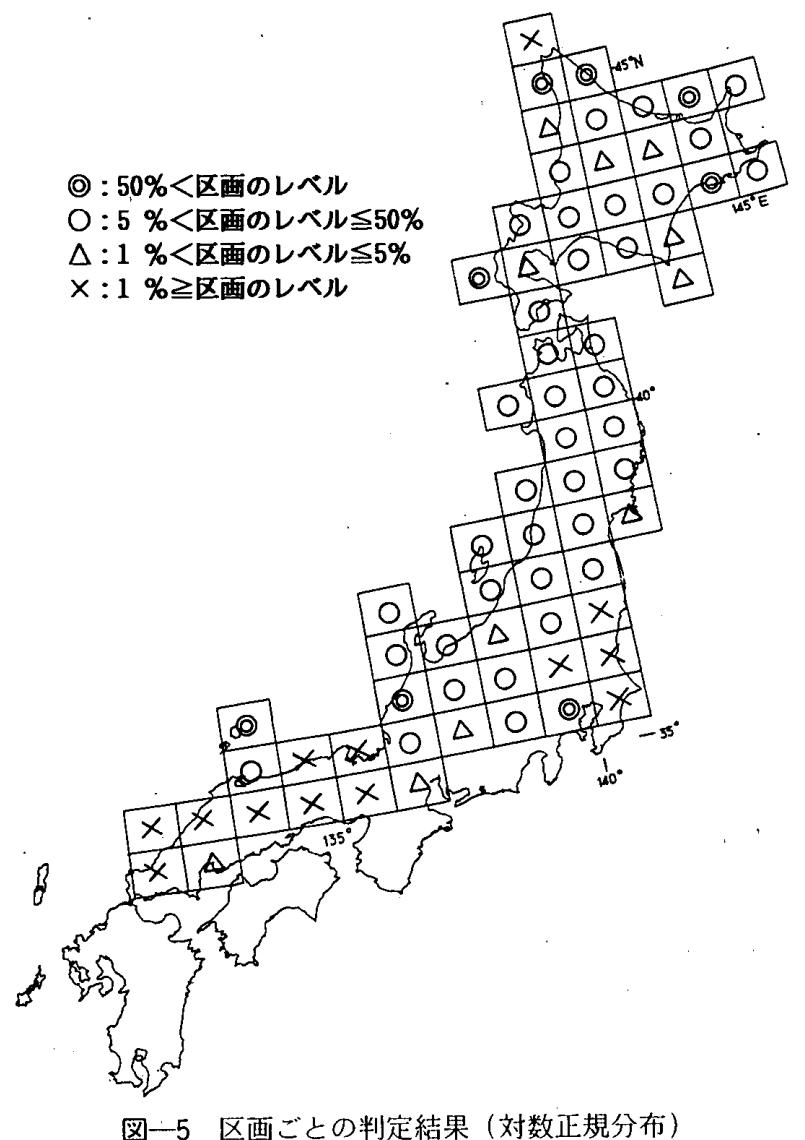

図一5に示すように，北海道，東北，北陸地方について は一部の区画を除きおおむね適合するが，中国地方など ではきわめて適合度が低く，四型およびI型分布に比べ 
表一3 観測地点ごとの最適分布形を用いて求められる期待値に 対する $5 つ の$ 確率分布形それぞれによる期待値の比

\begin{tabular}{|c|c|c|c|c|c|c|}
\hline \multicolumn{2}{|c|}{ 再現期間 } & I 型 & II 型 & III型 & 正規 & 対数 \\
\hline \multirow{2}{*}{10 年 } & $\overline{\mathrm{x}}$ & 1.00 & 1.07 & 1.00 & 0.98 & 1.07 \\
\cline { 2 - 7 } & $\sigma$ & 0.019 & 0.070 & 0.017 & 0.023 & 0.099 \\
\hline \multirow{2}{*}{30 年 } & $\overline{\mathrm{x}}$ & 1.01 & 1.41 & 0.98 & 0.91 & 1.18 \\
\cline { 2 - 7 } & $\sigma$ & 0.076 & 0.398 & 0.054 & 0.087 & 0.297 \\
\hline \multirow{2}{*}{50 年 } & $\overline{\mathrm{x}}$ & 1.01 & 1.66 & 0.97 & 0.88 & 1.25 \\
\cline { 2 - 7 } & $\sigma$ & 0.108 & 0.716 & 0.076 & 0.115 & 0.426 \\
\hline \multirow{2}{*}{100 年 } & $\overline{\mathrm{x}}$ & 1.02 & 2.14 & 0.96 & 0.85 & 1.34 \\
\cline { 2 - 7 } & $\sigma$ & 0.151 & 1.481 & 0.103 & 0.148 & 0.634 \\
\hline
\end{tabular}

期待值の比

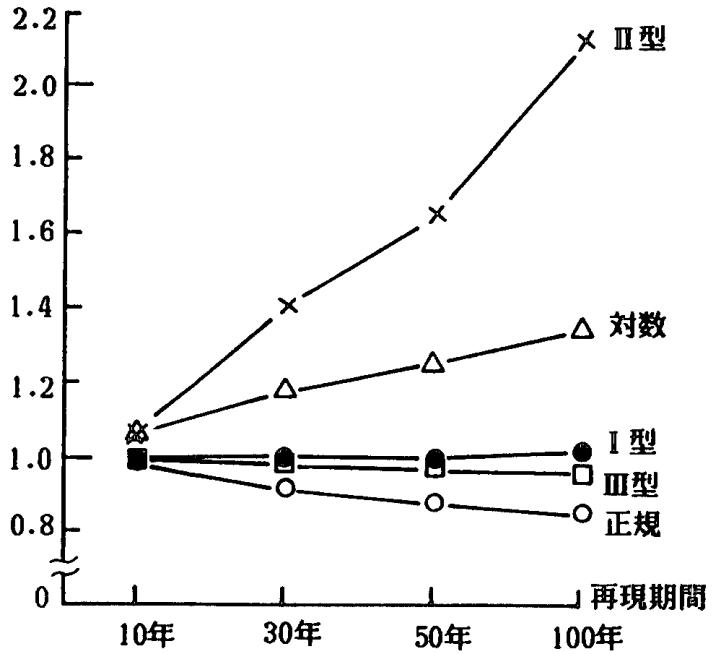

図一6 観測地点ごとの最適分布形を用いて求められる期待值に 対する 5 つの確率分布形それぞれによる期待值の比

全国的な適合性は劣る。

結局，これらの検討結果は，全国的に採用する単一の 確率分布形としてはIII型分布あるいは I 型分布が適当で あることを示しており, 確率分布形のパラメータの算定 あるいは荷重の組み合わせにおける雪荷重係数の算定な どにおける数值計算上の便宜さを考虑すればI型分布を 選定するほうが実用的であろう。

3.3 再現期待値

再現期待値はLRFD 試案，規準案などにおいて設計 用の公称值として用いられるので，確率分布形の特性に よって生じる差違を検討することも必要である。再現期 間 100 年までを対象期間として,$r$ 值の大小から定ま る観測地点ごとの最適分布形を用いて求められる年最大 積雪深の期待值に対する 5 つの分布形それぞれを一律に 用いて求められる年最大積雪深の期待値の比（以下，期 待値の比と記す）について，362 地点の平均值 $\bar{x}$ 之標準 偏差 $\sigma$ を表一 3 に示す。図一6には, 期待値の比の平均 値について再現期間ごとの推移を示す。各分布形とも再
50年期待値の比

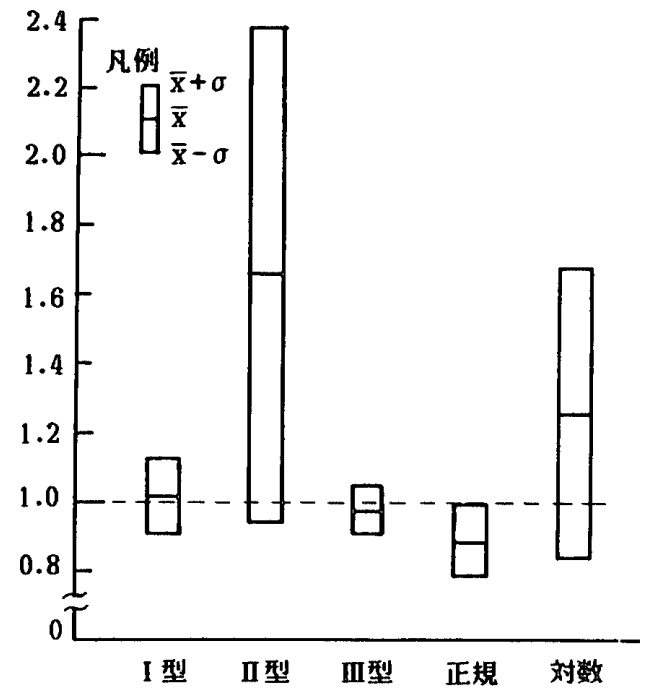

図一7観測地点ごとの最適分布形を用いて求められる 50 年期

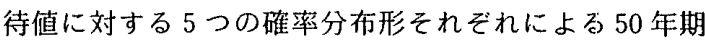
待值の比

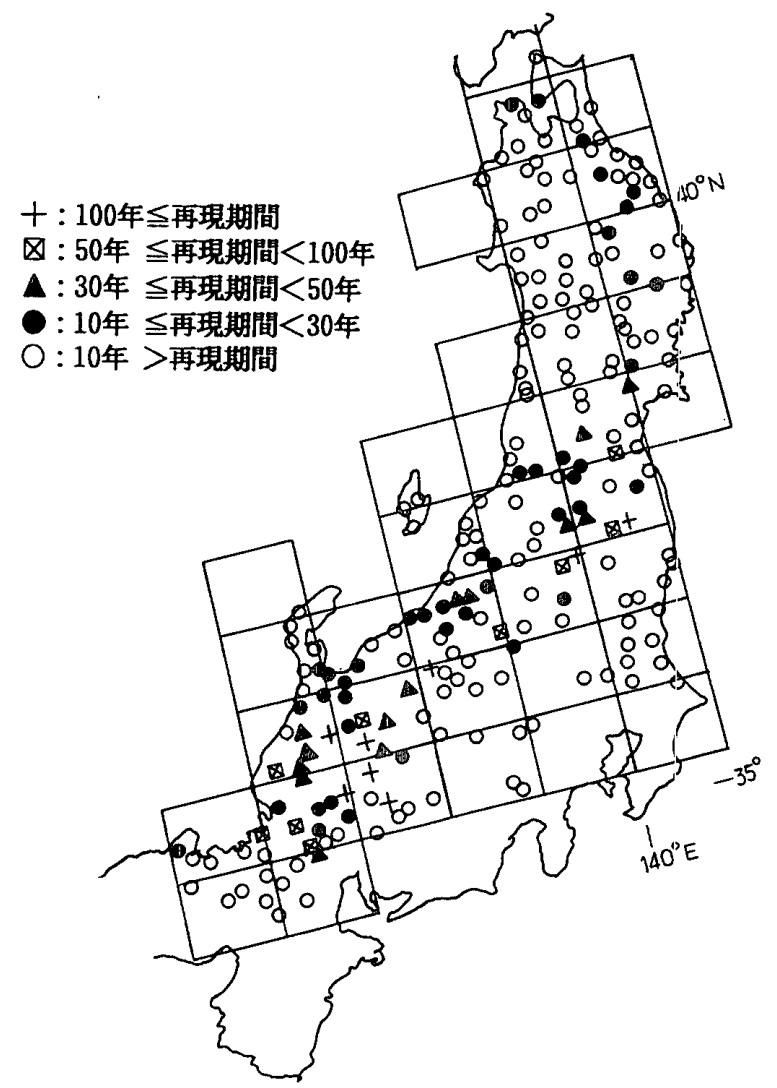

図一8「56 豪雪」年における各地の年最大積雪深に相当する再 現期間

現期間 10 年では期待値の比に大きな違いはみられない が，再現期間が大きくなるにつれ II 型分布および対数正 規分布は期待値を過大評価し，正規分布は過小に評価す る傾向がみられる。正型分布および I 型分布については, 再現期間 100 年までの範囲では期待値の比に大きな変化 は見られず 1.0 前後を推移している。また，図一7に再 現期間 50 年における期待値の比の值の 362 地点の平均 
值と標準偏差 $\sigma$ を示すが, II 型分布では $\sigma=0.716$, 対 数正規分布では $\sigma=0.426$ となり他の分布形に比べこの 2 分布形のばらつきが特に顕著である。したがってこれ らの結果は, 全国一律に適用するには不適切な確率分布 形を用いれば，II型分布および対数正規分布などのよう に，再現期間が大きくなるにつれ各地の再現期待値評価 においても大きな誤差が現れることを示している。

次に，大豪雪となった昭和 55～56 年冬期の各地の年 最大積雪深が，再現期間何年值に相当するのかを検討す る。前節では，極值而型分布あるいは極値 I 型分布を用 いることが適当であることを指摘したが，ここでは全地 点にI型分布を適用して再現期間を求める。各県で再現 期間の大きい地点は，例えば青森県七戸では 24 年 (141 $\mathrm{cm})$, 岩手県遠野 24 年 $(61 \mathrm{~cm})$, 宮城県白石 96 年 (59 $\mathrm{cm})$, 山形県山形 46 年 $(113 \mathrm{~cm})$, 福島県若松 44 年 $(115 \mathrm{~cm})$, 長野県長野 111 年 $(92 \mathrm{~cm})$, 岐皁県高山 100 年 $(128 \mathrm{~cm})$, 新潟県十日町 33 年 $(422 \mathrm{~cm})$, 富山 県富山 18 年 $(160 \mathrm{~cm})$, 福井県福井 75 年 $(196 \mathrm{~cm})$ な ビである。各地の再現期間は，図一-8のようになってい て，全地点が大きな期待年になっている訳ではなく，各 地で様々である（ただし同図では，ほとんどの地点が格 別に多雪の年ではなかった北海道と中国地方を除いてい る文11)。その中で北陸, 中部地方に，30 年以上の地点 が特に集中し，豪雪年の特徴を示している。

\section{4. 雪荷重係数}

総プロの資料を基に荷重・耐力係数設計式における雪 荷重係数について，考慮すべき顕著な地域的特性が見ら れるのかどうかを検討する。荷重の組み合わせとしては 雪荷重十固定荷重を対象とする。積載荷重については, 統計資料が十分ではないこと，またLRFD 試案では雪 荷重との組み合わせにおける積載荷重の平均値之固定荷 重の平均值との比 $\bar{L} / \bar{D}$ を 0.5 として設定しており，し たがって後述の $\bar{S} / \bar{D}$ における $\bar{D}$ を固定荷重十積載荷重 と読みかえることも可能であることから，本稿では組み 合わせ荷重から除いた。限られた地点数の統計量から求 めている LRFD 試案の荷重係数と 362 地点の荷重係数 とを対比して検討するため LRFD 試案とあわせて以下 の関係式，諸数値を用いた。すなわち，荷重係数 $\gamma$ は $\gamma=\left(1+\alpha \beta V_{w}\right) \bar{W} / W_{n}$ 式から得る。ここで雪荷重の確率 分布関数は前節までの結果から I 型分布とし, 雪荷重の 平均值/雪荷重の公称值 $\left(\bar{W} / W_{n}\right)$ については, 50 年最大

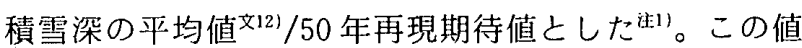
の 362 地点の平均値は 1.10 となり，1.07〜1.13 の範囲 に全地点の $93 \%$ が含まれている。雪荷重の変動係数 $V_{w}$ については, 屋根形状係数, 環境係数, 雪の単位重

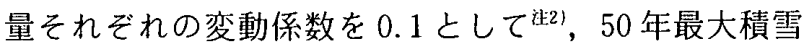
深の変動係数との二乗和の平方根から得た。 $V_{w}$ は,

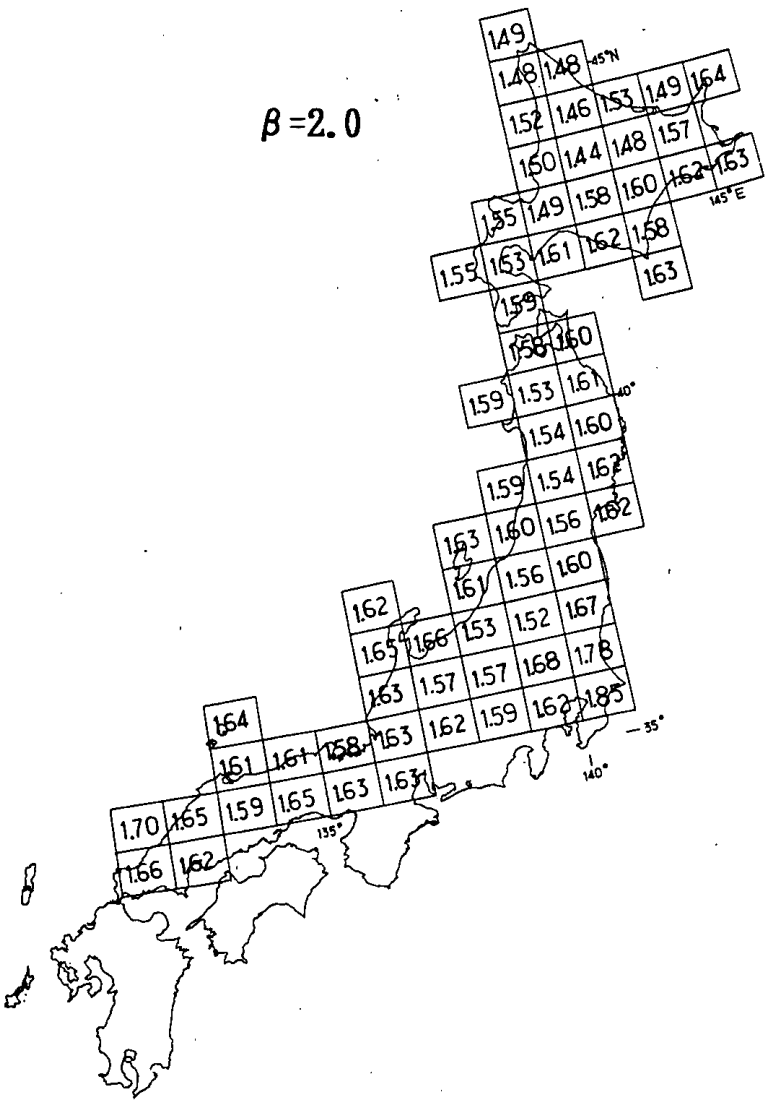

図一9 区画ごとの雪荷重係数

362 地点の平均值が 0.26 であり, 0.22 - 0.30 の範囲に 全地点の $93 \%$ が含まれている。また分離係数 $\alpha$ につい ては, 全地点一律に定数を与えるのではなく, 各地点ご とに破壊点において非正規確率分布を正規化近似する際 の繰返し計算によって求めた文13)。

終局耐力および固定荷重の確率分布関数ならびに標準 的な統計量は，終局耐力については対数正規分布，耐力 の平均值 $/$ 公称耐力 $=1.10$, 耐力の変動係数 $=0.15$, 固 定荷重については正規分布，“固定荷重の平均値／公称値 $=1.00$, 固定荷重の変動係数 $=0.10$ を設定した ${ }^{\ddagger 22 。}$

雪荷重係数值の地域分布を検討する際，基準区画ごと の代表值睟)を基にすればよりその地域特性を把握しや すい。図一 9 に許容安全性指標 $\beta=2.0$ の場合の雪荷重 係数の区画代表値を示す。北海道では 1.44 1.64 の範 囲にあり，道央から道北にかけてほぼ 1.5 ，その他亡゙は ほぼ 1.6 前後である。本州では $1.52 \sim 1.85$ の範囲にあ るが，関東地方の太平洋岸を除く地域では $1.5 \sim 1.7$ 程 度とみられる。したがって，全国的に雪荷重係数值に関 して差は小さいと言える。図一10には区画代表値のヒ ストグラムを示すが，全国平均值は 1.59 である。なお，

注）各区画の雪荷重係数代表値としては，観測点位置を正規 化した後区画を $10 \times 10$ の格子点に分割し，不規則に分布 する観測点のデータから各格子点の値を制約条件つき最適 化問題としてペナルティ法により求め, それから得られる 重み付き平均値を用いた。ただし，海の面積が大きい区画 などでは各観測点の単純平均值を採用した。 


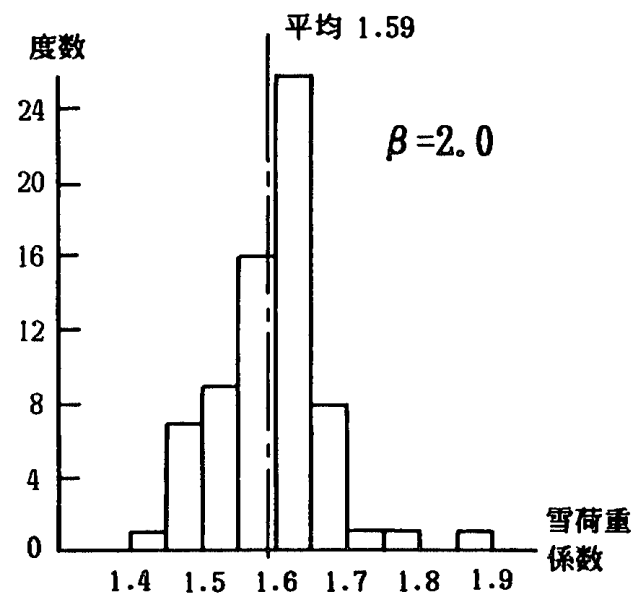

图一10 区画ごとの雪荷重係数のヒストグラム

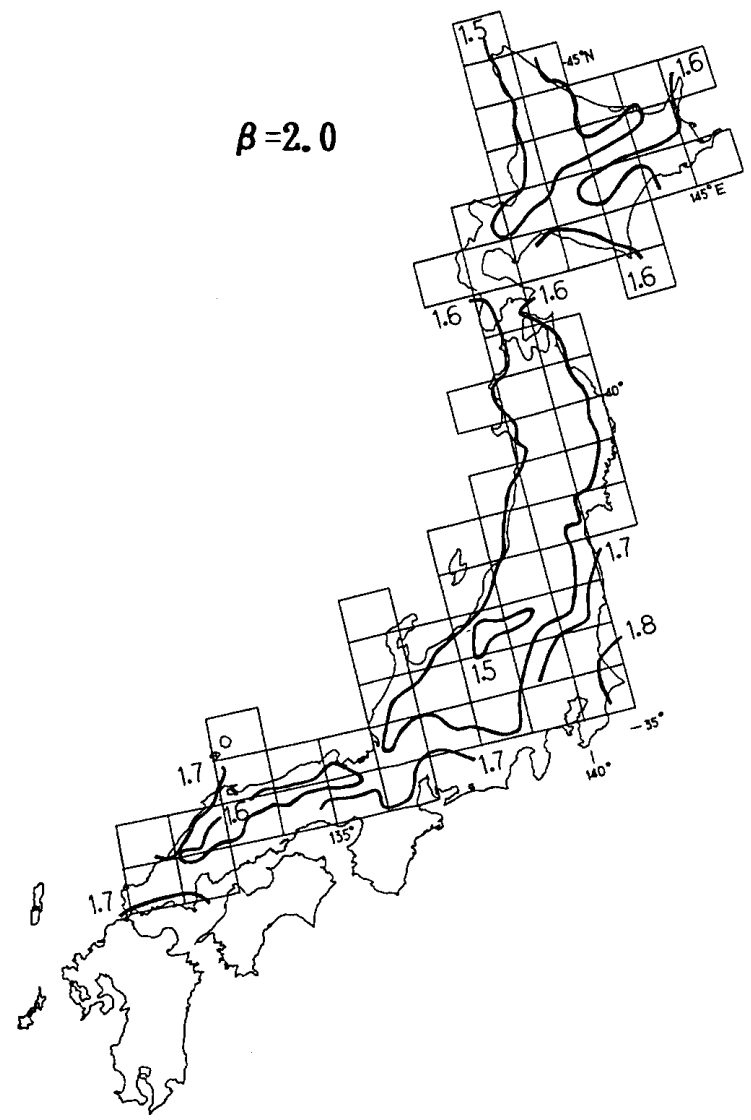

图一11 雪荷重係数のコンターマップ

362 地点個々の雪荷重係数値によるコンターマップロ(i3) 図一11に示すが，緯度と標高差による影響が見られる。 また, 雪荷重係数値 1.7 以下には 338 地点（全地点の $93 \%)$ が含まれる。

$\beta=2.5$ の場合での区画代表値は図一 12 のようにな る。北海道では 1.55 1.78 の範囲にあり，道央から道 北にかけてほぼ1.6，その他ではほぼ1.6〜1.8程度と みてよい。本州では $1.64 \sim 2.02$ の範囲にあり， $\beta=2.0$ の場合に比べ雪荷重係数値のばらつきがやや大きくな る。ただし, 関東地方の太平洋岸と山陰地方の一部が 1.85 以上であり，これを除く地域では $1.6 \sim 1.8$ 程度で
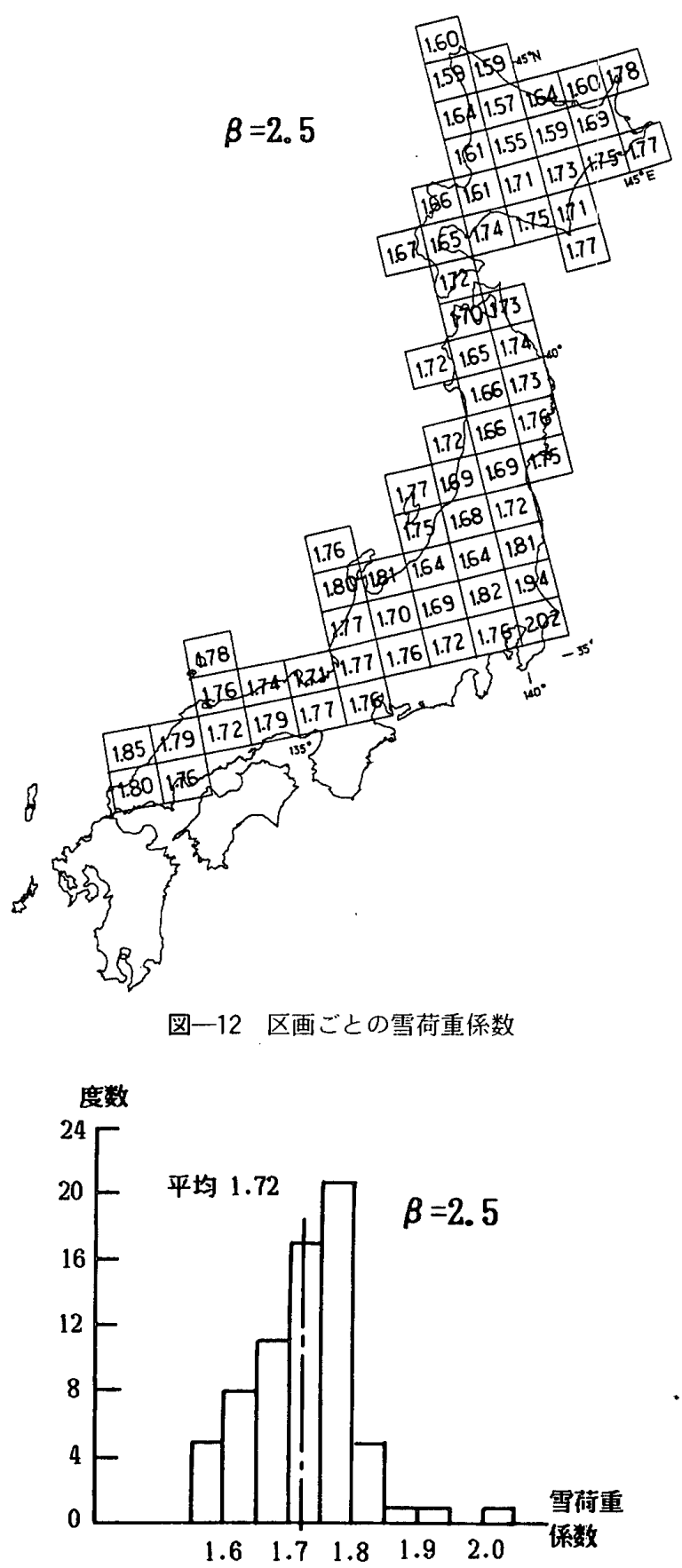

図一13 区画ごとの雪荷重係数のヒストグラム

あるので，雪荷重係数値に関する差は小さいといえる。 図一13 に示すように区画代表値の全国平均值ば 1.72 で ある。また，図一14にコンターマップを示すが，雪荷 重係数值 1.8 以下には 313 地点（全地点の $86 \%$ ）が含 まれる。なお，図一9１4 に示す雪荷重係数 $\gamma$ は雪荷重 の平均値と珤定荷重の平均值との比 $\bar{S} / \bar{D}=4$ の場合に おけるものである。 $\bar{S} / \bar{D}=2$ における $\gamma$ と $\bar{S} / \bar{D}=4$ に おける $\gamma$ の差は, 許容安全性指標 $\beta=2.0$ および $\beta=$ 2.5 のいずれにおいても, 362 地点のうちの最大の地点 でも $2 \%$ 程度でしかない。したがって，362 地点の $\bar{W} /$ $W_{n}, V_{w}$ および $\alpha$ それぞれの性状を考虑しても $\bar{S} / \bar{D}=2$ 以上では $\gamma$ を一定とみなすことができる。 


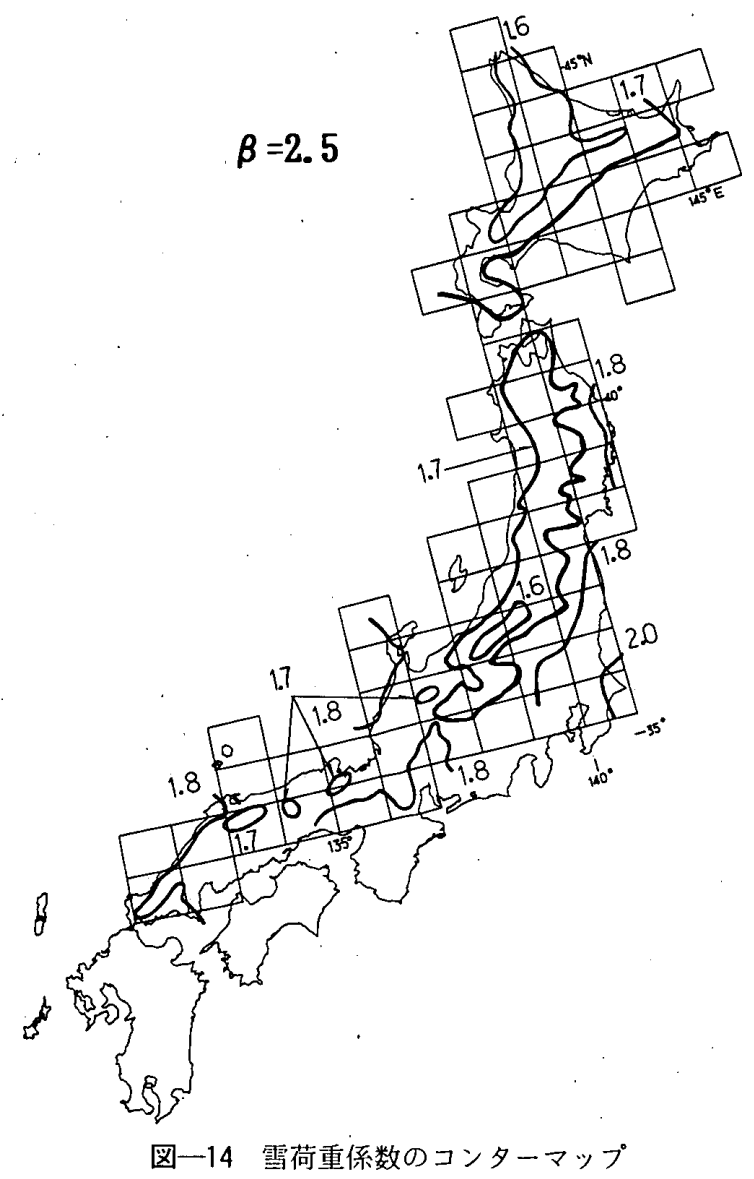

規準案に示されている雪荷重係数值 $1.6(\beta=2.0)$ は 荷重および耐力の確率分布関数を対数正規分布として, また雪荷重の基本統計量として年最大積雪深の変動係数 および平均値/公称値を用いて得られているので, 本稿 による雪荷重係数値との直接的な比較は意味をなさない が, 図一7に示すように, 雪荷重係数に乗ずるべき年最 大積雪深の 50 年期待値を対数正規分布に依拠して算定 するならば，確率分布関数を極值 I 型分布に設定した場 合に比べ雪荷重値は結果として過大に評価されることに なる。これに対し, 本稿の性能関数の構成は LRFD 試 案と基本的に同一なので (LRFD 試案では屋根形状係 数, 環境係数, 雪の単位重量などの変動係数の扱いが規 準案のように明示されていないが.) 雪荷重係数值相互の 此較ができよう。すなわち LRFD 試案では $\beta=2.5$ と して多雪地域における雪荷重係数值 2.0 が示されている が, 本稿の検討結果では対象地域のほぼ最大值に相当す る。

本稿での雪荷重係数の算定過程における反復計算から 得た分離係数 $\alpha$ は, $\beta=2.0$ の場合 362 地点の平均值が 0.86 となり, $0.83 \sim 0.88$ の範囲に全地点の $90 \%$ が含 まれる。また, 雪荷重係数值 1.7 に相当する值は 0.88 である。 $\beta=2.5$ の場合, 362 地点の平均値は 0.87 とな り，0.84〜0.89 の範囲に全地点の $95 \%$ が含まれる。ま た，雪荷重係数值 1.8 に相当する值はおよそ 0.88 であ る。

\section{5. 結 論}

四国と九州を除く全国 362 地点の年最大積雪深の統計 資料を基に，信頼性理論に基づいた設計法において用い 全国一律に用いられる確率分布形の適否によって, 各地 の積雪深の再現期待値評価に表れる差違について言及し た。さらに，荷重・耐力係数設計式における雪荷重係数 の地域分布について考察を加えた。本研究により得られ た結論は以下のとおりである。

た結論は以下のとおりである。

（1）観測記録への 5 つの分布形（極值 I 型分布，極値 II 型分布，極值 III型分布，正規分布，対数正規分布）そ れぞれの適合度をFillibenの方法によって検定したが， III型およびI型分布が全国的によく適合することが示さ れた。 $5 \%$ 検定では，前者は全地点の $93 \%$ ，後者は 88 $\%$ が合格となる。対数正規分布は，北海道，東北，北 陸地方においては一部地域を除きおおむねあてはまる が，5\% 検定では全地点の $34 \%$ が不合格となり III型・ I 型には及ばない。特に，中国地方においてきわめて適 合性が低い結果となった。正規分布は $5 \%$ 検定不合格 率が $43 \%$ ，II 型分布では $68 \%$ となり上位 3 分布に比 ベ劣るが，とりわけ II 型分布の適合性の低さが顕著であ る。したがって，全国的に用いるべき単一の確率分布形 としては型分布あるいはI型分布が適当であり，確率 分布形のパラメータの算定あるいは荷重の組み合わせに おける雪荷重係数の算定などについての数値計算上の便 宜さを考慮すればI型分布を選定するほうが実用的であ 万う。

（2）全国一律に単一の確率分布形を用いたときの再現 期待值について，各観测地点ごとに判定される適合度順 位 1 位の分布形を用いて求められる再現期待值との対比 を行った。再現期間 10 年程度では $5 つ$ つ分布形の期待 值には大きな違いはみられない。しかし，再現期間が大 きくなるにつれ II 型分布と対数正規分布は期待値を過大 に，逆に正規分布は過小に評価する傾向がみられ，全国 一律に適用するには不適切な確率分布形を用いれば，各 地の年最大積雪深の再現期待値評価において大きな誤差 が現れることが示された。

（3）雪荷重＋固定荷重の組み合わせにおける各地の雪 荷重係数 $\gamma\left(\gamma=\left(1+\alpha \beta V_{w}\right) \bar{W} / W_{n}\right)$ の地域分布特性につ いて検討した。ただし, 確率分布関数は雪荷重を極値 I 型分布，固定荷重を正規分布，終局耐力については対数 正規分布とした。許容安全性指標 $\beta$ として 2.0 を設定 した場合の第 1 次地域区画ごとの代表值は，北海道では 道央から道北にかけてほぼ 1.5 ，その他ではほぼ 1.6 前 後である。本州では, 関東地方の太平洋岸においては 1.7 を超えるが，それを除く地域では 1.5 1.7 程度で ある。また， $\beta=2.5$ の場合は，道央から道北にかけて ほぼ1.6，その他ではほぼ1.6〜1.8 程度とみてよい。 
本州では, 関東地方の太平洋岸と山陰地方の一部が 1.85 以上であり，これを除く地域では $1.6 \sim 1.8$ 程度で ある。したがって， $\beta=2.0$ および $\beta=2.5$ のいずれに おいても雪荷重係数值に関して顕著な地域的違いはみら れないことが示された。

\section{6.あとがき}

本稿では四国と九州を除外して考察したが，これらの 地域の観測記録の処理については別の機会に検討する予 定である。

\section{謝 辞}

本研究は北海道大学 柴田拓二教授のご指導のもとに 行われたものである。深甚なる謝意を申し上げます。解 析に用いる資料としては，建設省総合技術開発プロジェ クト「雪に強い都市づくりに関する総合技術の開発」建 築構造部会において作成した積雪資料を使わせて頂きま した。雪荷重係数の算定にあたっては名古屋大学 河野 守博士, 東京職業訓練短期大学校 高橋利恵博士加ら有 益な助言を頂きました。また，J.J. Filliben 博士には 貴重な示唆を頂きました。併せて感謝申し上げます。

\section{注}

1）基準期間を 50 年として, 雪荷重の平均値および雪荷重の 公称値を次式のように設定した。

雪荷重の平均值 $\bar{W}=C \cdot E \cdot \rho \cdot \bar{Y}_{s 5}$

雪荷重 $の$ 公称值 $W_{n}=C \cdot E \cdot \rho \cdot Y_{n 50}$

ここで $C$ : 屋根形状係数

$E:$ 環境係数

$\rho:$ 積雪の単位重量相当値

$\bar{Y}_{s 50}: 50$ 年最大積雪梁の平均値

$Y_{n 50}: 50$ 年積雪深再現期待值

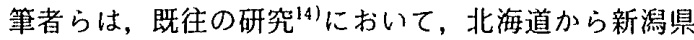
にいたる多雪地域の年最大地上積雪重量記録および同時 観測された年最大地上積雪深記録について，極值 I 型分 布を設定し次の知見を得ている。すなわち，積雪の単位 重量相当値 $\rho$ は, 再現期間 100 年までの範围においては, 再現期間にかかわりなく同一地点においてほぼ一定であ り,また地域間の変差も小さいため, $\rho=3.5\left(\mathrm{kgf} / \mathrm{m}^{2} / \mathrm{cm}\right)$ とみなしてよく, 年最大積雪重星の再現期待值 $\left(\mathrm{kgf} / \mathrm{m}^{2}\right)$ $=3.5 \times$ 年最大積雪深の再現期待值 $(\mathrm{cm})$ の関係が成立 する。I 型分布では 50 年最大積雪梁の平均値 $\bar{Y}_{s 50}$ はほ ぼ 90 年再現期待値 $\left(Y_{n 90}\right)$ に相当するので, (1)式において $\bar{Y}_{s 50}$ を便宜的に $Y_{n 90}$ と読みかえることが可能である。し たがって，(1)式および(2)式における 3.5 を設定することができる。ただし，多雪地域以外の 一般の地域においては，統計処理を行えるだけの積雪重 量記録が得られていないのが現状なので，具体的な数値 は特定せず，50 年再現期待值と 90 年再現期待值の $\rho$ は 同等であることのみを仮定した。また，屋根形状係数と 環境係数は，それぞれを(1)式および(2)式において同等な ものとして設定した。したがって，これらから雪荷重の 平均値/雪荷重の公称檤 $=50$ 年最大積雪深の平均値 $/ 50$ 年 積雪深再現期待値として扱い，積雪深から荷重へ変換す ることができる。
2）屋根形状係数，環境係数および雪の単位重量それぞれの 変動係数，終局耐力および固定荷重の確率分布関数なら びに標準的な統計量なよ゙については，これらの統計的特 性の評価に立入ることは本稿の主旨ではない。しかし LRFD 試案に示されている雪荷重係数値と比較するため に，LRFD 試案に依拠して設定した。ただし，札幌市内 に建つ無暖房大型陸屋根倉庫における筆者らの 8 冬期間 の実測調查によれば，屋根形状係数の変動係数はおよそ 0.14 (屋根形状係数については別の機会に報告する予定 である) であり，設定値 0.1 は札幌についてはほぼ妥当 である。また，積雪の単位重量相当値の変動係数は，筆 者らの研究 ${ }^{15)}$ によれば, 我が国の多雪地域において 0.14 である。したがって, 設定値 0.1 は概略値として適当で ある。環境係数の変動係数については，屋根上積雪量に 及ぼす環境因子についての検討を含めて，統計的に処理 できるだけの資料が必ずしも得られていないことから適 正值の評価が難しいため，暫定的に 0.1 を纳定している。

3）地上の積雪深は気象要因および地理的・地形的要因なよ゙ によって大きく影響を受け，観測資料のない地点の再現 期待值などの推定は容易ではない。これに対し，雪荷重 係数值は, 各観測地点の気象的条件および地理的・地形 的条件が異なるにもかかわらず，本稿で対象とした 362 地点についてはその地域的差違が小さいことは注目すべ きことである。このことから気象要因および地理的・地 形的要因を無視して，雪荷重係数値の平面的分布のみに 基づいてコンターマップを作成しても大きな誤差はない と考えられる。本稿では, 観測地点が適当に散在してい ること，また雪荷重係数値の同位の地点が連続して分布 していることを目視によって判断できることを利用して コンターマップを得た。すなわち，雪荷重係数值のみに 基づいて，各区域を包含する仮のラインを目視によって 引くことができる。それをはさんで近接している各観測 地点の平面上での相対的位置関係から，相互の筜荷重係 数値差を比例配分して得られる地点を基本にして,コン ターラインを描いた。

\section{参考文献。}

1）前田博司：積雪深の極值分布，福井工業大学砂究紀要, 第 10 号, pp. 23 -31，1980 年

2）和泉正哲，三橋博三，高橋 徹：年最大積雪深の確率統 計的性質之再現期問値推定法，日本建築学会棈造系論文 報告集，第 390 号，pp. 49 58，1988 年 8 月

3）藤野陽三，伊藤 学，酒井利夫：年最大風速記録による 設計基本風速の算定に関する研究，土木学会論文報告集， 第 305 号, pp. 23〜 34，1981 年 1 月

4) Filliben, J. J. : The Probability Plot Correlation Coefficient Test for Normality, Technometrics, Vol.17, No. 1, pp. 111 117, 1975

5）河野 守, 坂本 順, 青木和雄：荷重の確率過程の組み 合わせにおける超過確率の理論解とその応用に関する考 察，日本建築学会構造系論文報告集，第 405 号，pp. 31 ４0，1989 年 11 月

6) Ellingwood, B. and Redfield, R. : Ground Snow Loads for Structural Design, Structural Engineering, No.4, pp. 950 963, 1983

7） E. J. Gumbel：極值統計学，河田竜夫，岩井重久，加瀬 滋男監訳，生産技術セン夕一新社，1978 年 
8） H-S. Ang, H. Tang : 土木建築のための確率・統計の応 用, 伊藤 学, 黾田弘行, 黒田勝彦, 藤野陽三共訳, 丸 善. 1988 年

9) Schueller, G. I. : 構造物の安全性と信頼性, 小西一郎, 高岡宣善, 石川，浩訳，丸善，1984 年

10）桜井修次, 藤田久志, 城 攻, 紫田拓二：北海道, 東北, 北陸地方の年最大積雪記録に関する統計解析, 日本建築 学会大会学術講演梗概集 B, pp. 41 42, 1986 年

11）昭和 56 年豪篦被害調查報告：日本建築学会, 1981 年

12）神田 順：限界状態設計法での荷重の扱い, 建築技術, pp. 204 212, 1991 年 7 月号
13）星谷 勝, 石井 清: 構造物の信頼性設計法, 鹿島出版 会 1986 年 5 月

14）桜井修次, 城 攻, 紫田拓二：多雪地域における地上 最大積雪重量の検討, 日本建築学会大会学術講演梗概集, pp. 1149 1150, 1982 年

15）桜井修次, 城 攻, 柴田拓三：設計用雪荷重評価のた めの年最大地上積雪重量の確率・統計的性質に関する考 察, 日本建築学会構造系論文報告集, 第 437 号, 1992 年 7 月号揭載予定

(1991 年 9 月 3 日原稿受理, 1992 年 3 月 23 日採用決定) 